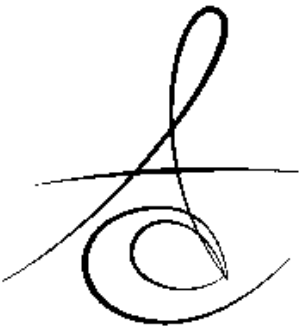

\title{
ASSESSMENT OF FORAMEN MAGNUM AND CLIVUS FOR ESTIMATION OF AGE AND GENDER USING CONE-BEAM CT
}

\section{YAŞ VE CİNSİYET TAYİNİNDE FORAMEN MAGNUM VE KLİVUSUN KONİK IŞINLI BT KULLANIMI İLE DEĞERLENDİRİLMESİ}

\author{
Dr. Öğr. Üyesi Seval BAYRAK*
}

Dr. Öğr. Üyesi Duygu GÖLLER BULUT*

Makale Kodu/Article code: 3748

Makale Gönderilme tarihi: 25.06.2018

Kabul Tarihi: 15.11 .2018

\section{ABSTRACAT}

Aim: The aim of this study is to perform morphometric analysis of the foramen magnum (FM) and clivus using cone-beam computed tomography (CBCT) and to evaluate their applicability in age and gender estimation.

Materials and Methods: CBCT images of 412 individuals (248 females and 164 males) were included in the study. The sagittal dimension (SD) and transverse dimension (TD) and area of the FM were measured. The width and length of clivus were calculated. The data were statistically analyzed with ANOVA, Kruskal-Wallis and t-tests to assess the level of significance for sex and age.

Result: The mean values of SD, TD, area of FM and width and length of clivus were higher in males than in females. Statistically significant differences were found between sexes for all variables $(p<0.05)$. There was no statistically difference between age and FM dimensions $(p>0.05)$. There was a significant relationship and positive correlation between length of clivus and age groups ( $p=0.009, r=0.351)$.

Concusion: CBCT provides valuable information about the dimensions of the FM and clivus, and can be used reliably for anthropometric analysis and forensic medicine in the field of sexual dimorphism. The length of clivus can also help in determining age groups.

Keywords: Age estimation, CBCT, clivus, foramen magnum, sex estimation

\section{öz}

Amaç: Bu çalışmanın amacı foramen magnum (FM) ve klivusun morfometrik özelliklerini konik ışınlı bilgisayarlı tomografi (KIBT) ile belirleyip ve yaş ve cinsiyet belirlemede kullanılabilirliğini değerlendirmektir.

Materyal ve Metod: 412 bireye (248 bayan ve 164 erkek) ait KIBT görüntüsü çalışmaya dahil edildi. FM' un sagittal boyutu (SB), transversal boyutu (TB) ve alanı ölçüldü. klivusun genişlik ve uzunluğu ölçüldü. Veriler, cinsiyet ve yaş için önem düzeyini değerlendirmek amacıyla ANOVA, Kruskal-Wallis ve ttestleri ile istatistiksel olarak analiz edildi.

Bulgular: SB, TB, FM alanı ile klivus genişliği ve uzunluğuna ait ortalama değerler erkeklerde kadınlara nazaran yüksek bulundu. Tüm değişkenler için cinsiyetler arasında istatistiksel olarak anlamlı fark görüldü $(p<0.05)$. Yaş ve FM boyutları arasında istatistiksel olarak farklılık yoktu $(p>0.05)$. Klivusun uzunluğu ile yaş grupları arasında anlamlı bir ilişki ve pozitif korelasyon görüldü $(p=0.009, r=0.351)$.

Sonuç: KIBT, FM ve klivus boyutları hakkında değerli bilgiler sağlar ve cinsiyet ayrımında antropometrik ve adli tıp alanında güvenilir bir şekilde kullanılabilir. Ayrıca klivusun uzunluğu da yaş gruplarının belirlenmesinde yardımcı olabilir.

Anahtar Sözcükler: Yaş tayini, KIBT, klivus, foramen magnum, cinsiyet ayrımı

\footnotetext{
* Bolu Abant Izzet Baysal University Faculty of Dentisty Department of Dentomaxillofacial Radiology, Bolu.
} 


\section{INTRODUCTION}

In physical anthropology, skull is most studied skeletal remain for sex estimation. ${ }^{1}$ It is difficult to define anatomical structures prior to many surgical procedures, so morphometric analysis of the skull is routinely performed by clinical anatomists. In addition, anthropologists can distinguish the age, sex, and race of individuals by physical morphology of face and head. ${ }^{2}$ However, gender discrimination poses a major problem in the unknown human skeleton, especially for legal anthropology. It is almost always impossible and complicated to find a perfectly sound skeleton in explosions or battles, because of the fragmentation of the bones and the presence of parts of the victims' bodies, so it is necessary to apply them correctly and carefully. ${ }^{2,3}$ The pelvis is the best and skull is the second best area for gender estimation because the craniofacial structures are less affected by environmental factors and comparatively undamaged. ${ }^{3}$ Previous studies have shown that the length of the skull, the circumference and height of the head, the mastoid process, the occipital condyle, measurements were made. ${ }^{2-6}$ Forensic age estimation is also needed to identify unidentified bodies and skeletons. Age estimation is important for the legal responsibilities and definitions of living individuals. In current years, migration movements have increased and this increased the demand for estimating the age of living individuals. ${ }^{7}$

Foramen magnum (FM) is a 3-dimensional opening in the basal central region of the occipital bone, and at the same time a transition region between the spine and the skull. ${ }^{2}$ FM is an important anatomical landmark due to its position between the brain and spinal cord ${ }^{6}$ and is an area of interest for anatomy, anthropology, forensic medicine and other medical fields. ${ }^{4}$ Radiographic methods can be used to determine gender by giving the actual dimensions of FM to which certain formulas can be used. ${ }^{8}$

The clivus is a part of the skull base located between the dorsum sellae and magnum. Clivus has a more dense bone structure than the other parts of the skull. It can be saved without being damaged by a burned or damaged skull. Even after burning, clivus can alternatively be used for medical gender estimation with anthropometric measurements. ${ }^{9}$ The clivus formation is caused by the fusion of the synchondrosis between the exoccipital and basioccipital bones. After the fusion, it starts to grow. The process of ossification of the clivus starts from the third year and continues until the age of 25 to create basophanoid and basiocciput. ${ }^{1,10}$

Cone beam computed tomography (CBCT) is a relatively new technology that is used primarily for many applications in the dentomaxillofacial region. ${ }^{11}$ $\mathrm{CBCT}$ is used in both pre and post-mortem forensic practices and has previously been used for identification ${ }^{8}$, age prediction ${ }^{12}$, sex estimation ${ }^{13}$, restructuring ${ }^{14}$ and bite analysis. ${ }^{15}$

In the present study, clivus and FM were assessed quantitatively by $\mathrm{CBCT}$ by measuring the width and length of clivus in axial and sagittal section respectively and measuring the sagittal diameter, transvers diameter and the area of the FM in the axial section to determine their medicolegal and forensic significance in morhphometric analysis.

\section{MATERIALS AND METHODS}

The study protocol was conducted according to the principles set out in the Declaration of Helsinki, and ethical approval was granted by the Local Ethics Committee of the Medical Faculty of the University.

A total of 412 CBCT images of the skull were analysed from the database of the Dentomaxillofacial Radiology Department of the Bolu Abant Izzet Baysal University by I-Cat System (Imaging Sciences International, Hatfield, PA, USA) Invivo 5. The voxels were isotropic and in $0.3 \mathrm{~mm}$ size. Only high quality reconstructed full Field of View (FOV) CBCT images without artefacts were selected. Images with trauma or any surgery history in the skull were excluded. Scans that included full of FM and clivus were assessed.

i. Sagittal Dimension (SD) of FM: The maximum length was measured in the anteroposterior direction along the main axis of the foramen magnum (Fig. 1A).

ii. Transverse Dimension (TD) of FM: The largest transverse diameter of the foramen magnum was measured to be approximately perpendicular to SD (Fig. 1B).

iii. Area of FM; calculated automatically by using Invivo 5 (Anatomage, Inc, San Jose, USA) (Fig. 
1C).

iv. The length of clivus (LC) was defined as the longest distance superio-inferiorly from the upper point of dorsum sella to the lowest point on anterior margin of foramen magnum and it was measured on sagittal section in CBCT (Fig 2A).

v. The width of clivus (WC) was defined as the longest distance from left to right side near the anterior peripheral margin of foramen magnum inferiorly and it was measured on axial sections in CBCT (Fig 2B).

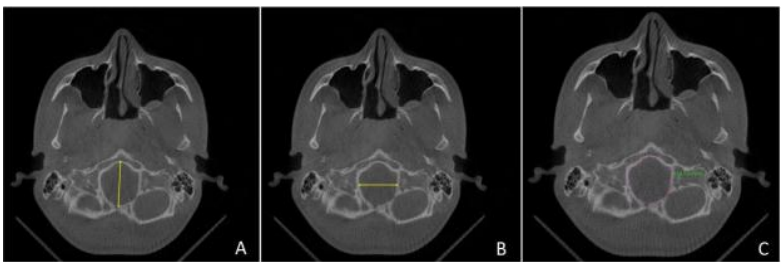

Figure 1.Sagittal diameter $(A)$, transverse diameter (B), area of foramen magnum (C).

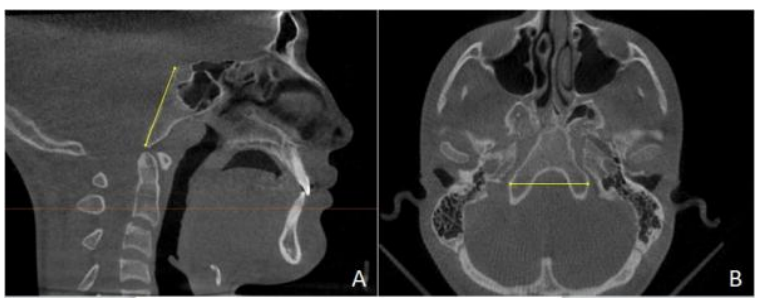

Figure 2.Length (A) and width (B) of clivus.

\section{Statistical Analysis}

Statistical analyses were conducted with SPSS

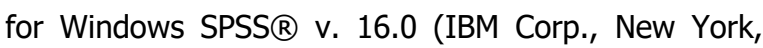
NY; formerly SPSS Inc., Chicago, IL). Variables between groups were compared using independent $t$ test between two groups and one-way analysis of variance (ANOVA) test and post-hoc (Gabriel) test for multiple groups comparisons if the data were normally distributed. The Kruskal-Wallis test with post-hoc (Mann-Whitney $\mathrm{U}$ with the Bonferroni correction) was performed to analysis differences between data that not normally distributed. Values of $p<0.05$ were considered to indicate statistical significance.

\section{RESULTS}

All measurements were performed independently by an oral radiologist with 8 years of experience. Randomly selected $20 \%$ CBCT images were evaluated again after 2 weeks to assess the intra-observer's calibration (Pearson correlation coefficients for SD of FM: 0.92 , TD of FM: 0.94, area FM: 0.97, LC: 0.92, WC: 0.93).

In total 412 individuals (248 females, $\% 60.2$ and 164 males, $39.8 \%$, mean age \pm standard deviation: $17.05 \pm 10.8$ ) were observed. Majority of the study subjects were between 14 to 15 years of age $(27.7 \%)$ followed by subjects 12 to 13 years (25.2\%), subjects 16 to 17 years (16\%), upper than 18 years (17.5\%) and lower than 11 years (13.6\%) (Table 1). SD, TD, and the area of the FM and length and width of the clivus were calculated in both genders. Table 2 showed the descriptive values of parameters according to genders. There were significant differences between sexes for all variables. Mean values of all measurements were lower in females than in males $(p<0.05)$.

Table 3 shows the descriptive values of all measurements according to age groups. When the measurements were evaluated according to age groups regardless of gender difference, no statistically significant difference was found between all measurements and age groups except the length of clivus ( $p=0.009, r=0.351)$. In Table 4, LC and WC were evaluated separately for women and men according to age groups. For LC, there were significant differences between the age groups in both males and females ( $p=0.006, p=0.02$ respectively).

Table 1. The distribution of age groups.

\begin{tabular}{ccc}
\hline Age Group & Number of individuals & Percent \\
\hline$\leq 11$ & 56 & 13.6 \\
$12-13$ & 104 & 25.2 \\
$14-15$ & 114 & 27.7 \\
$16-17$ & 66 & 16.0 \\
$18 \leq$ & 72 & 17.5 \\
Total & 412 & 100.0 \\
\hline
\end{tabular}


Atatürk Üniv. Diş Hek. Fak. Derg.

Table 2. Descriptive values and statistical analyses for all parameters-sex comparative results.

\begin{tabular}{|c|c|c|c|c|c|c|}
\hline Variables & Sex & Minimum (mm) & Maximum (mm) & Mean & Std. Deviation & $P$ value \\
\hline \multirow{2}{*}{ SDFM (mm) } & Male & 16.31 & 44.14 & 33.5994 & 4.74742 & \multirow{2}{*}{$0.044 *$} \\
\hline & Female & 15.44 & 40 & 32.2592 & 4.16894 & \\
\hline \multirow{2}{*}{ TDFM (mm) } & Male & 24.18 & 44.55 & 37.0687 & 4.36493 & \multirow{2}{*}{$0.003 *$} \\
\hline & Female & 24.54 & 42.89 & 36.2502 & 3.48333 & \\
\hline \multirow{2}{*}{$\begin{array}{c}\text { Area FM } \\
\left(\mathbf{m m}^{2}\right)\end{array}$} & Male & 354.73 & 1239.04 & 906.0517 & 174.04215 & \multirow{2}{*}{$0.002 *$} \\
\hline & Female & 265.43 & 1157.32 & 850.0767 & 156.0461 & \\
\hline \multirow{2}{*}{ LC $(\mathbf{m m})$} & Male & 35.84 & 52.01 & 45.8538 & 3.51437 & \multirow{2}{*}{$0.000 *$} \\
\hline & Female & 34.54 & 52.56 & 44.0984 & 3.66837 & \\
\hline \multirow{2}{*}{ WC (mm) } & Male & 3215 & 54.43 & 44.8741 & 3.84217 & \multirow{2}{*}{$0.003^{*}$} \\
\hline & Female & 34.36 & 50.64 & 42.9065 & 4.8792 & \\
\hline
\end{tabular}

SDFM; Sagittal dimension of foramen magnum, TDFM; transverse dimension of foramen magnum, area FM; area of foramen magnum, LC; length of clivus, WC; width of clivus.

$*$ Difference is statistically significant $\mathrm{P}<0.05$ levels.

Table 3. The difference between age groups for all subjects in parameters.

\begin{tabular}{|c|c|c|c|c|c|c|c|}
\hline Variables & Age Groups & $\mathbf{N}$ & Mean & Std. Deviation & Minimum & Maximum & P value \\
\hline \multirow{6}{*}{ SDFM (mm) } & $\leq 11$ & 56 & 37.4650 & 2.2006 & 33.48 & 42.89 & \multirow{6}{*}{0.053} \\
\hline & $12-13$ & 104 & 37.5354 & 3.2125 & 26.27 & 43.47 & \\
\hline & $14-15$ & 114 & 36.2895 & 3.7365 & 24.54 & 44.55 & \\
\hline & $16-17$ & 66 & 36.2133 & 3.8061 & 25.12 & 41.31 & \\
\hline & $18 \leq$ & 72 & 35.2850 & 5.4176 & 24.18 & 43.9 & \\
\hline & Total & 412 & 36.5760 & 3.8691 & 24.18 & 44.55 & \\
\hline \multirow{6}{*}{ TDFM (mm) } & $\leq 11$ & 56 & 34.0071 & 2.8483 & 29.05 & 40 & \multirow{6}{*}{0.110} \\
\hline & $12-13$ & 104 & 33.3671 & 3.8257 & 16.09 & 40.15 & \\
\hline & $14-15$ & 114 & 32.8495 & 3.7573 & 15.71 & 40.1 & \\
\hline & $16-17$ & 66 & 32.4415 & 4.4628 & 15.44 & 39.16 & \\
\hline & $18 \leq$ & 72 & 31.2503 & 6.5689 & 16.31 & 44.14 & \\
\hline & Total & 412 & 32.7927 & 4.4459 & 15.44 & 44.14 & \\
\hline \multirow{6}{*}{ Area FM $\left(\mathrm{mm}^{2}\right)$} & $\leq 11$ & 56 & 897.0268 & 112.2139 & 737.39 & 1113.94 & \multirow{6}{*}{0.078} \\
\hline & $12-13$ & 104 & 903.5444 & 141.2314 & 333.73 & 1239.04 & \\
\hline & $14-15$ & 114 & 882.8551 & 140.9252 & 265.43 & 1216.16 & \\
\hline & $16-17$ & 66 & 852.5515 & 197.9177 & 279.68 & 1165.34 & \\
\hline & $18 \leq$ & 72 & 809.6597 & 217.2589 & 354.73 & 1179.34 & \\
\hline & Total & 412 & 872.3580 & 165.3274 & 265.43 & 1239.04 & \\
\hline \multirow{6}{*}{ WC (mm) } & $\leq 11$ & 56 & 43.9589 & 3.8511 & 36.88 & 51.09 & \multirow{6}{*}{0.344} \\
\hline & $12-13$ & 104 & 43.9423 & 2.9846 & 38.31 & 52.91 & \\
\hline & $14-15$ & 114 & 44.0512 & 6.3578 & 4.36 & 54.43 & \\
\hline & $16-17$ & 66 & 43.1888 & 4.3998 & 31.71 & 49.67 & \\
\hline & $18 \leq$ & 72 & 43.0025 & 3.9248 & 36.14 & 50.85 & \\
\hline & Total & 412 & 43.6898 & 4.5879 & 4.36 & 54.43 & \\
\hline \multirow{6}{*}{ LC (mm) } & $\leq 11$ & 56 & 43.3064 & 3.2600 & 36.18 & 49.45 & \multirow{6}{*}{$p=0.009 * r=0.351$} \\
\hline & $12-13$ & 104 & 44.4035 & 3.6709 & 37.47 & 52.56 & \\
\hline & $14-15$ & 114 & 45.4404 & 3.2073 & 39.08 & 52.01 & \\
\hline & $16-17$ & 66 & 45.1812 & 4.1179 & 35.34 & 51.04 & \\
\hline & $18 \leq$ & 72 & 45.3656 & 4.1840 & 34.54 & 51.27 & \\
\hline & Total & 412 & 44.4163 & 3.7572 & 34.54 & 52.56 & \\
\hline
\end{tabular}


Table 4. The difference between age groups for man and woman individuals in length and width of clivus

\begin{tabular}{|c|c|c|c|c|c|c|c|c|}
\hline & Variables & Age groups & $\mathbf{N}$ & Mean & Std. Deviation & Minimum & Maximum & p value \\
\hline \multirow{12}{*}{ MALE } & \multirow{6}{*}{ LC (mm) } & $\leq 11$ & 18 & 43.21 & 3.00062 & 38.77 & 47.97 & \multirow{6}{*}{$0.006^{*}$} \\
\hline & & $12-13$ & 42 & 45.255 & 3.23859 & 38.91 & 51.72 & \\
\hline & & $14-15$ & 46 & 46.959 & 3.17381 & 41.33 & 52.01 & \\
\hline & & $16-17$ & 20 & 48.086 & 2.2559 & 44.27 & 51.04 & \\
\hline & & $18 \leq$ & 38 & 45.759 & 3.95217 & 35.84 & 51.27 & \\
\hline & & Total & 164 & 45.739 & 3.51437 & 35.84 & 52.01 & \\
\hline & \multirow{6}{*}{ WC $(\mathrm{mm})$} & $\leq 11$ & 18 & 45.699 & 3.90402 & 39.25 & 51.09 & \multirow{6}{*}{0.594} \\
\hline & & $12-13$ & 42 & 44.971 & 3.09149 & 40.2 & 52.91 & \\
\hline & & $14-15$ & 46 & 45.842 & 3.60964 & 41.62 & 54.43 & \\
\hline & & $16-17$ & 20 & 43.911 & 4.96451 & 32.15 & 49.22 & \\
\hline & & $18 \leq$ & 38 & 43.712 & 4.15942 & 36.85 & 50.85 & \\
\hline & & Total & 164 & 44.874 & 3.84217 & 32.15 & 54.43 & \\
\hline \multirow{12}{*}{ FEMALE } & \multirow{6}{*}{ LC (mm) } & $\leq 11$ & 38 & 43.352 & 3.45433 & 36.18 & 49.45 & \multirow{6}{*}{$0.02 *$} \\
\hline & & $12-13$ & 62 & 43.827 & 3.88129 & 37.47 & 52.56 & \\
\hline & & $14-15$ & 68 & 44.413 & 2.83654 & 39.08 & 50.16 & \\
\hline & & $16-17$ & 46 & 43.918 & 4.13273 & 35.34 & 50.45 & \\
\hline & & $18 \leq$ & 34 & 44.982 & 3.56719 & 34.54 & 46.57 & \\
\hline & & Total & 248 & 44.098 & 3.66837 & 34.54 & 52.56 & \\
\hline & \multirow{6}{*}{ WC $(\mathrm{mm})$} & $\leq 11$ & 38 & 43.135 & 3.63898 & 36.88 & 50.64 & \multirow{6}{*}{0.615} \\
\hline & & $12-13$ & 62 & 43.246 & 2.74399 & 38.31 & 49.67 & \\
\hline & & $14-15$ & 68 & 42.84 & 7.49415 & 4.36 & 50.52 & \\
\hline & & $16-17$ & 46 & 42.875 & 4.21117 & 31.71 & 49.67 & \\
\hline & & $18 \leq$ & 34 & 42.209 & 3.60097 & 36.14 & 49.5 & \\
\hline & & Total & 248 & 42.907 & 4.8792 & 4.36 & 50.64 & \\
\hline
\end{tabular}

$L C$; length of clivus, WC; width of clivus. * Difference is statistically significant p $<0.05$ levels.

\section{DISCUSSION}

The estimation of the skeleton and the separating human remnants is one of the most difficult issues in forensic medicine. By using metric or morphological methodologies, gender identification can be successful. If almost all of the bones that make up the skeleton are present, gender estimation is easier. Craniofacial structures have the advantage of being formed from a largely rigid tissue, which is relatively harmless. ${ }^{4,16} \mathrm{FM}$ is an important and vital structure of the skull base. It has been found that the dimensions between male and female. ${ }^{17}$ But this sexual dimorphisms specific to the population, as indicated by the studies related to the people of Iraq ${ }^{4}$,
Turkey ${ }^{18}$ Brazil ${ }^{19}$, Poland, 20 and Nigeria. ${ }^{21}$ The dimensions of FM are influenced by genetic, environmental and social factors. With this in mind, we conducted our research on the population of the province $x$ in the western Black Sea region in Turkey. FM completes its growth in early childhood. It does not respond to secondary sexual changes, has no effect on size and shape of muscles, and become fairly stable after puberty. ${ }^{17}$

When the previous studies measuring SD and TD of FM were evaluated; Murshed et al. ${ }^{22}$ (by using $\mathrm{CBCT}$ ) found the mean SD values to be $37.2 \pm 3.43 \mathrm{~mm}$ and $34.6 \pm 3.16 \mathrm{~mm}$, and the mean TD values to be $31.6 \pm 2.99 \mathrm{~mm}$ and $29.3 \pm 2.19 \mathrm{~mm}$ in males and females respectively. According to the Kanchan et al. ${ }^{23} \mathrm{SD}$ was $34.51 \mathrm{~mm}$ in and $33.6 \mathrm{~mm}$ and TD was $27.36 \mathrm{~mm}$ and $26.74 \mathrm{~mm}$ in males and females respectively. Babu et al. ${ }^{24}$ stated the mean value of

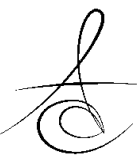


the SD in males and females as $35.68 \mathrm{~mm}$ and 32.57 $\mathrm{mm}$ and TD as $28.91 \mathrm{~mm}$ and $28.19 \mathrm{~mm}$. In the study of Uthman et al. ${ }^{4}$ (by using Helical CT) (18), the mean value of SD of FM was $34.9 \mathrm{~mm}$ for males and $32.9 \mathrm{~mm}$ for females. The mean of TD of FM was 29.5 $\mathrm{mm}$ and $27.3 \mathrm{~mm}$ in males and females, respectively.

According to the Ilgüy et al. ${ }^{25}$ reported that on $\mathrm{CBCT}$ images, SD was $37.7 \pm 2 \mathrm{~mm}$ in males and $35.6 \pm 4 \mathrm{~mm}$ in females; and TD was $32.6 \pm 2 \mathrm{~mm}$ in males and $31.0 \pm 2$ in females, close to the results reported in Murshed's ${ }^{22}$ study. In the study of Raikar et al. ${ }^{17}$, the mean values of SD were $34.19 \pm 3.57 \mathrm{~mm}$ for males and $32.49 \pm 3.17 \mathrm{~mm}$ for females. The means of TD were $31.77 \pm 3.59 \mathrm{~mm}$ in males and $29.66 \pm 2.71 \mathrm{~mm}$ in females. Akay et al.(by using $\mathrm{CBCT})^{2}$ reported the mean values of SD in males and females as 36.4 and $34.6 \mathrm{~mm}$ and TD as $31.2 \mathrm{~mm}$ and $29.8 \mathrm{~mm}$, respectively. In the study of Tellioğlu et al. ${ }^{26}$ (by using CT), in males mean SD was $34.73 \pm 2.21$ $\mathrm{mm}$, TD was $30.47 \pm 2.25 \mathrm{~mm}$, in females mean SD was $32.99 \pm \pm 2.65 \mathrm{~mm}$, TD was $28.4 \pm 2.72 \mathrm{~mm}$. When we evaluate the results of these studies it was noticeable that the measurement averages are higher in men and there are significant differences between the genders $(p<0.05)$. Similarly, the mean values of SD and TD in males were higher than in females in the present study. The differences in the mean values of SD and TD might be due to the difference between the anatomic methods and radiographic techniques used in the previous studies.

The area of FM was automatically calculated using the Invivo 5 (Anatomage) software program. When we examined the literature, we observed that researchers used two formulas to calculate this area: the Texeira formula and the Radinsky formula. Among the Indian studies; Kanchan et al. ${ }^{23}$ and Babu ${ }^{24}$ used both formulas in their work and determined that the field value obtained by Radinsky's formula was a better determinator of gender. Catalina-Herrera 27 stated the mean values of the FMA in female and male skulls as $801 \mathrm{~mm}^{2}$ and $888.4 \mathrm{~mm}^{2}$, respectively. In the study conducted on Turkish skulls Gunay et al ${ }^{28}$ found The area of FM as $909.91 \pm 126.02 \mathrm{~mm}^{2}$ for males and $819.01 \pm 117.24 \mathrm{~mm}^{2}$ for females. Uthman et al. ${ }^{4}$ measured the The area of FM and the results showed a mean value of $670.2+93.7 \mathrm{~mm}^{2}$ for females and $765.2+98 \mathrm{~mm}^{2}$ for males. Tellioğlu et al. ${ }^{26}$ and Raikar et al. ${ }^{17}$ reported The area of $\mathrm{FM}$; in men as $8.17 \mathrm{~cm}^{2}$ and $800.72 \mathrm{~mm}^{2}$, in women $727 \mathrm{~mm}^{2}$ and 769.9 $\mathrm{mm}^{2}$, respectively. These results were slightly lower than those of the present study. In the present study The area of FM was measured as $850.05 \pm 156.04 \mathrm{~mm}^{2}$ for females and $906,05 \pm 174,04 \mathrm{~mm}^{2}$ for males. No statistically significant difference was found between the age groups without sex difference for all measurements over FM.

Clivus matures at the age of 11 in both sexes and reaches its final length at this age. It then remains constant throughout life. Eleven years of postnatal life is very important, because the adult width of the clivus is reached at this age. According to Jehan and Kumar ${ }^{9}$, male had higher mean clivus length and width than females and this difference was statistically significant ( $p<0.0001)$. In the study of Chaurasia et al. ${ }^{1}$, mean clivus width and length was $28.8 \pm 3.98$ and $42.7 \pm 3.98 \mathrm{~mm}$ respectively, regardless of age and sex. Statistically, there was no significant difference between sexes $(p>0.05)$ in clivus width. However, the clivus length in both male and female populations was statistically significant ( $p$ $<0.001$ ). In the male population, the clivus length was greater. Pearson's correlation between age and clivus length and width showed a significant positive correlation $(r=0.285, p<0.001$ and $r=0.465, p=$ 0.001 respectively). These findings are summarized in the previous study of Chaurasia et al. ${ }^{29}$. Similar results were obtained in our study, there was a significant relationship and positive correlation between length of clivus and certain age groups $(p=0.009, r=0.351)$. Because of the strong positive correlation between clivus length and age, clivus length has played an important role in determining age. If the length of the clivus is known, we can estimate the age of the patient. This is a very revolutionary step in the field of forensic science. The present study has also come to the conclusion that clivus length has changed significantly in both sexes.

$\mathrm{CBCT}$ is proposed as an alternative imaging modality that can be used to assess biological parameters such as age and sex, to assess trauma, and to predict personal identification. Compared to conventional CT units, CBCT units are cheaper; have higher spatial resolution providing isotropic images; there is a fast scan time; it provides easier access and interaction with data and ease of use and convenience by reducing the need for operation. Low dose 
radiation with $\mathrm{CBCT}$ also provides an advantage when compared to $\mathrm{CT}$ because it is important to protect operators in non-specific locations such as the field or forensic sites or laboratories. For this reason, CBCT is used to compare skeletal structures in both premortem and post mortem imaging phases. However, because of the inadequate soft tissue contrast and limited applications with maxillofacial region and extremities, $\mathrm{CBCT}$ is not completely replaceable with classic CT. ${ }^{8}$

In conclusion, according to the results of this study, there is a significant relationship between the gender of the individuals and the sagittal and transverse dimension and area of the foramen magnum and the length and width of the clivus. There was also a significant relationship between the length of the clivus and the ages of the individuals. These significant parameters may be reliably used for sexual dimorphism and age estimation in forensic medicine and anthropometric analysis. CBCT can be used for pre and post mortem imaging in forensic medicine applications.

Seval Bayrak: ORCID ID: 0000-0003-0819-4578

Duygu Göller Bulut: ORCID ID: 0000-0003-4260-2520

\section{REFERENCES}

1. Chaurasia A, Patil R, Katheriya G. Radiomorphometeric Evaluation of Clivus in Indian Paediatric Population Visiting a Tertiary Dental Hospital-A Cone Beam Computed Tomography Study. J Clin \& Diagnostic Res 2018; 12

2. Akay G, Gungor K, Peker I. Morphometric analysis of the foramen magnum using cone beam computed tomography. Turk J Med Sci 2017; 47: 1715-22.

3. Gunay $Y$, Altinkok $M$. The value of the size of foramen magnum in sex estimation. J Clin Forensic Med 2000; 7:147-9.

4. Uthman AT, Al-Rawi NH, Al-Timimi JF. Evaluation of foramen magnum in gender estimation using helical CT scanning. Dentomaxillofac Radiol 2012; 41:197-202.

5. Jain D, Jasuja OP, Nath S. Sex estimation of human crania using Mastoid triangle and Opisthion-Bimastoid triangle. J Forensic Leg Med 2013; 20:255-9.
6. Kanchan T, Gupta A, Krishan K. Estimation of sex from mastoid triangle - a craniometric analysis. J Forensic Leg Med 2013; 20:855-60.

7. Bayrak S, Halicioglu S, Kose G, Halicioglu K. Evaluation of the relationship between mandibular condyle cortication and chronologic age with cone beam computed tomography. J Forensic Leg Med 2018; 55:39-44.

8. Tambawala SS, Karjodkar FR, Sansare K, Prakash $N$, Dora AC. Sexual dimorphism of foramen magnum using Cone Beam Computed Tomography. J Forensic Leg Med 2016; 44:29-34.

9. Jehan M, Kumar R. Sexual dimorphism of clivus dimension by computed tomography scan. Indian Journal of Applied Research 2014; 9:379-81.

10. Hofmann E, Prescher A. The clivus: anatomy, normal variants and imaging pathology. Clin Neuroradiol 2012; 22:123-39.

11. Aktan $A$, Güngör $E$, Çiftçi $M$, İşman Ö. Diş hekimliğinde konik işinli bilgisayarli tomografi kullanimi. Atatürk Üniversitesi Diş Hekimliği Fakültesi Dergisi 2015; 25:71-6.

12. Yang F, Jacobs R, Willems G. Dental age estimation through volume matching of teeth imaged by cone-beam CT. Forensic Sci Int 2006; $159: 78-83$.

13. Gamba Tde O, Alves MC, Haiter-Neto F. Mandibular sexual dimorphism analysis in CBCT scans. J Forensic Leg Med 2016; 38:106-10.

14. Lee KM, Lee WJ, Cho JH, Hwang HS. Threedimensional prediction of the nose for facial reconstruction using cone-beam computed tomography. Forensic Sci Int 2014; 236:191-5.

15. Marques J, Musse J, Caetano C, Corte-Real F, Corte-Real AT. Analysis of bite marks in foodstuffs by computer tomography (cone beam CT)--3D reconstruction. J Forensic Odontostomatol 2013; 31:1-7.

16. Patil KR, Mody RN. Estimation of sex by discriminant function analysis and stature by regression analysis: a lateral cephalometric study. Forensic Sci Int 2005; 147:175-80. 
17. Raikar NA, Meundi MA, David CM, Rao MD, Jogigowda SC. Sexual dimorphism in foramen magnum dimensions in the South Indian population: A digital submentovertex radiographic study. J Forensic Dent Sci 2016; 8:180.

18. Uysal S, Gokharman D, Kacar M, Tuncbilek I, Kosa $U$. Estimation of sex by 3D CT measurements of the foramen magnum. J Forensic Sci 2005; 50:1310-4.

19. Galdames ICS, Russo PP, Matamala DAZ, Smith RL. Sexual dimorphism in the foramen magnum dimensions. International J of Morph 2009; 27

20. Burdan F, Szumilo J, Walocha J, Klepacz L, Madej B, Dworzanski W, Klepacz R, Dworzanska A, Czekajska-Chehab E, Drop A. Morphology of the foramen magnum in young Eastern European adults. Folia Morphol (Warsz) 2012; 71:205-16.

21. Bello SS ZA, Kalale SB, Usman JD, Bello A, Abdulhameed $A$, et al. . Measurements of Foramen Magnum using ComputerisedTomography in Sokoto State, Nigeria. Int J Health and Medical Information 2013; 2:29-35.

22. Murshed KA, Çiçekcibaşi AE, Tuncer I. Morphometric evaluation of the foramen magnum and variations in its shape: a study on computerized tomographic images of normal adults. Turk J Med Sci 2003; 33:301-6.

23. Kanchan T, Gupta A, Krishan K. Craniometric analysis of foramen magnum for estimation of sex. Int J of Med, Health, Biomed and Pharmac Engineering 2013; 7:111-3.

24. Raghavendra Babu YP, Kanchan T, Attiku Y, Dixit PN, Kotian MS. Sex estimation from foramen magnum dimensions in an Indian population. J Forensic Leg Med 2012; 19:162-7.

25. Ilguy D, Ilguy M, Ersan N, Dolekoglu S, Fisekcioglu E. Measurements of the foramen magnum and mandible in relation to sex using $\mathrm{CBCT}$. J Forensic Sci 2014; 59:601-5.

26. Tellioglu AM, Durum Y, Gok M, Karakas S, Polat AG, Karaman CZ. Suitability of foramen magnum measurements in sex estimation and their clinical significance. Folia Morphol (Warsz) 2018; 77:99104.
27. Catalina-Herrera CJ. Study of the anatomic metric values of the foramen magnum and its relation to sex. Acta Anat (Basel) 1987; 130:344-7.

28. Günay Y, Altinkök M, Cagdir S, Kirangil B. Gender estimation with skull measurements. J Forensic Med 1997; 13:4-8.

29. Chaurasia A, Katheriya G, Patil R. Radiomorphometric evaluation of Clivus in Indian ethinicity-A cone beam computed tomography study. Journal of Oral Medicine, Oral Surgery, Oral Pathology and Oral Radiology 2017; 3:35-41.

\section{Yazışma Adresi}

Dr. Seval Bayrak

Abant Izzet Baysal University Faculty of Dentisty Dentomaxillofacial Radiology, BOLU, TURKEY.

Business Tel: +90 3742538361

Fax Number: +90 3742600066

E-mail address: dtseval@hotmail.com 